\title{
A májfunkció vizsgálata respirometriával
}

\section{Examination of liver mitochondria with respirometry}

\author{
STRIFLER GERDA, MÉSZÁros ANDRÁS, PÉCZ DANIELlA, FICZERE ÁGNES, BARÁTH BÁLINT, \\ BOROS MIHÁLY, HARTMANN PETRA ${ }^{\circledR}$
}

\author{
Szegedi Tudományegyetem, Általános Orvostudományi Kar, Sebészeti Mütéttani Intézet, Szeged \\ (tanszékvezető: Dr. Boros Mihály)
}

\begin{abstract}
A mitochondriumok kulcsfontosságú élettani feladataiknál fogva oki szerepet játszanak számos akut és krónikus májbetegség kialakulásában, így e sejtalkotók terápiás és lehetséges diagnosztikus célpontok is egyben. Jelen tanulmányunk során bemutatunk egy vizsgálómódszert, amely nagy felbontású respirométer (oxigráf) segítségével lehetővé teszi a mitochondrialis funkciók értékelését. A vizsgálatok során friss szövetminták oxigénfogyasztásának meghatározása alapján az oxidatív foszforilációt és a mitochondrialis légzési lánc működését nagy pontossággal, valós időben lehet vizsgálni. A respirometriás módszer lehetőséget adhat a mütét elött vagy alatt vett biopsziákból a májmitochondriumok funkcionális vizsgálatára is, így hozzájárulhat a sebészeti beavatkozások hatékonyságának növeléséhez.
\end{abstract}

Kulcsszavak: mitochondrium, ischaemia/reperfúzió, respirometria, patkány

Due to their diverse physiological functions, mitochondria can cause various acute and chronic liver diseases, thus being potential targets for therapies and diagnostics as well. In this study, the advantages of high-resolution respirometry are presented for the assessment of liver mitochondrial functions. During respitometry, the mitochondrial electron transport, the oxydative phosphorilation and the efficacy of the ADP synthesis can be calculated on the basis of oxygen consumption of freshly-taken tissue samples. Respirometry is a robust tool for the pre- or intraoperative analysis of liver mitochondrial functions and may increase the effectiveness of surgical interventions.

Keywords: mitochondria, ischemia/reperfusion, respirometry, rat

Beérkezett: 2016. április 25.; elfogadva: 2016. június 6.

\section{Bevezetés}

A májfunkciók mütét előtti értékelése a sebészi kockázatelemzés fontos eleme, intraoperatív körülmények között pedig információt nyújthat az épben történő metszés határának vagy a transzplantálhatóság megítélésének szempontjából is. A jelenleg használt funkcionális módszerek közé főként biokémiai tesztek, képalkotó és szövettani eljárások tartoznak. ${ }^{1}$ A rutin-laborvizsgálatok során végzett májfunkciós tesztek (például az alanin- és aszpartát-aminotranszferáz enzim szintjének meghatározása) specificitása és érzékenysége kielégítő mértékü, de csak indirekt módon adnak információt a májsejtek metabolikus müködéséröl. A májminták hagyományos szövettani vizsgálata pedig időigényes, és az értékelés erősen függ a vizsgáló személyétől. ${ }^{2}$

A májsejtek metabolikus aktivitásáról és energiahomeosztázisáról a mitochondrialis funkciók értékelése közvetlen és objektív információt nyújthat, de az eddigi vizsgálóeljárások nem tették lehetővé e módszerek rutin diagnosztikai alkalmazását. A mitochondrialis belső membránjában található légzési lánc négy komplexből (I., II., III., IV. komplex), egy lipidkomponensböl (ubikinon), valamint a hem-csoportot tartalmazó citokróm c fehérjéböl áll. A légzési lánc müködése során elektronokat továbbít a végső elektronakceptor oxigénmolekula felé, miközben az ioncsatornaként is funkcionáló komplexeken keresztül protonokat pumpál ki a mátrixból az intermembrántérbe. A létrejövő protongradienst az ATP-szintáz használja fel müködéséhez, amely a belső membrán mátrix felőli oldalán az $\mathrm{ADP} \rightarrow$ ATP átalakulásért felel. Az I-IV. légzési komplexek a belső membránban egymással összekapcsolódva, úgynevezett szuperkomplexek formájában találhatók meg ${ }^{3}$.

Az oximetria szövetminták oxigénfogyasztásának meghatározására szolgáló eljárás, az oxigráffal a mitochond-

\footnotetext{
${ }^{\circledR}$ Levelezési cim/Corr. address: Dr. Hartmann Petra, Szegedi Tudományegyetem, Általános Orvostudományi Kar, Sebészeti Mütéttani Intézet, 6720 Szeged, Szőkefalvi-Nagy Béla u. 6. Telefon: +36 62545 743; E-mail: hartmann.petra@med.u-szeged.hu
} 


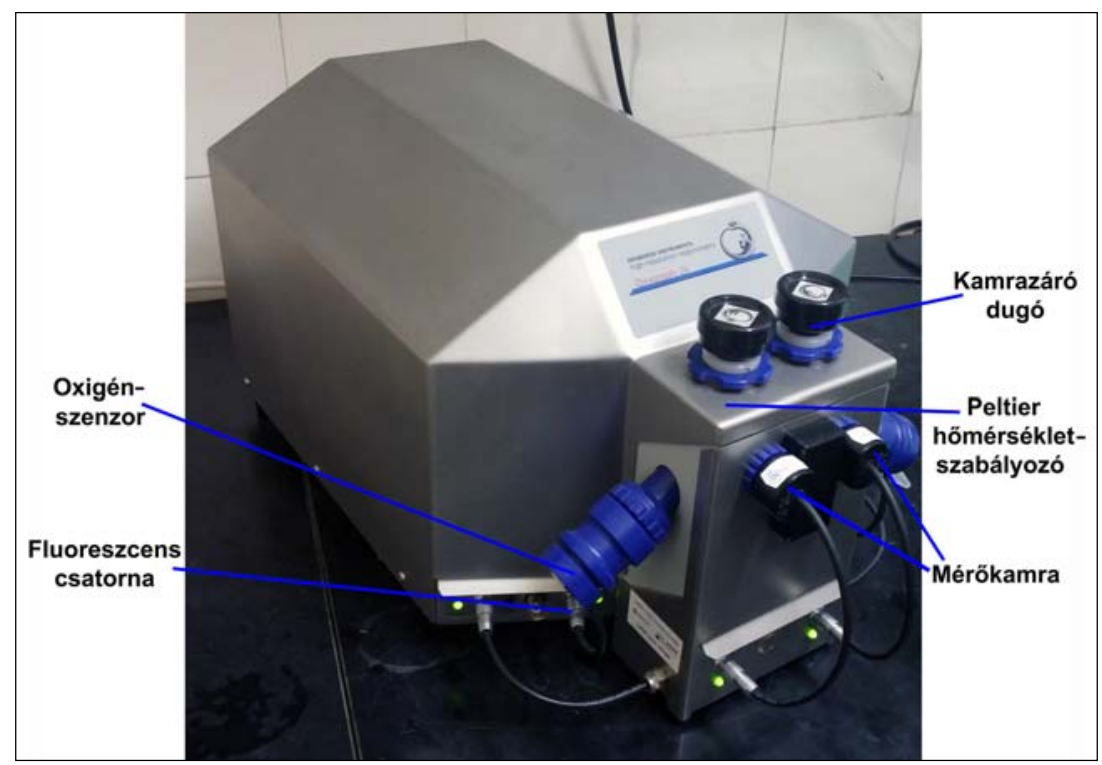

1. ábra. Oxygraph-2k nagy felbontású respirométer

rialis elektrontranszportot, az oxidatív foszforilációt és az ATP-szintézis hatékonyságát lehet megítélni. ${ }^{4}$ Az új generációs oxigráfokkal lehetőség nyílik kisméretü $(\geq 10 \mathrm{mg})$ minták, akár finomtü-biopsziát követő vagy mütétek során vett biopsziák fagyasztás nélküli vizsgálatára. ${ }^{5}$ Jelen tanulmányunk célja a standardizált, kísérletes körülmények között végzett, nagy felbontású respirométer segítségével történő mitochondriumvizsgálatok bemutatása volt.

\section{Anyag és módszerek}

Kísérleteinket az Állatkísérleti Tudományos Etikai Tanács (ÁTET) jóváhagyásával végeztük (Munkahelyi Állatjóléti Bizottság - MÁB) (engedélyszám: V./148/2013). A mitochondriumok in vitro vizsgálatára a humán minták fogadására is alkalmas OROBOROS Oxygraph-2k (Innsbruck, Ausztria) nagy felbontású respirométert és kiegészítő LED2 fluoreszcens modult használtuk (1. ábra). A respirométer a Clark-elektród (bipoláris elektrokémiai oxigénszenzor) elvén müködő mérőrendszer, amely nagy pontossággal képes biológiai minták pillanatnyi oxigénfogyasztásának meghatározására és követésére. Az elektródot polipropilén memb- rán borítja, ami oxigénre és szén-dioxidra permeábilis, de nem ereszti át a vizet és az ionokat, továbbá megakadályozza olyan vegyületek bejutását az elektródokhoz, amelyek azokat károsíthatják vagy zavarhatják a mérést. A kicsiny katódfelület, a zárt mintatartó és a minta keverése biztosítja, hogy a minta térfogatában az oxigénkoncentráció állandó, amit a katódon történő oxigénfogyasztás nem befolyásol. Ez adja az oxidatív foszforiláció mint alapvető mitochondriumfunkció vizsgálatának az alapját.

A módszer további tulajdonsága, hogy a mitochondrium légzési láncának komplexei müködés közben szelektíven vizsgálhatók, miközben valós időben követhetők a változások. A mitochondrialis funkciók meghatározása során a terminális oxidációban részt vevő komponenseket szubsztrátok és inhibitorok használatával lehet vizsgálni. A májból vett mintából homogenizátumot készítünk, amelyhez elöször glutamát (2 mM) és malát $(10 \mathrm{mM})$-szubsztrátok hozzáadásával aktiváljuk az I. komplexet, majd indukáljuk az oxidatív foszforiláció folyamatát ADP-vel (2,5 mM). Szukcinát $(10 \mathrm{mM})$ hozzáadásával aktiválódik a II. komplex, ezáltal meghatározható az I. és II. komplex maximális aktivitása. Ha rotenonnal $(0,5 \mu \mathrm{M})$ gátoljuk az I. komplexet, külön-külön mérhetővé válik az I. és a II. komplex kapaci-

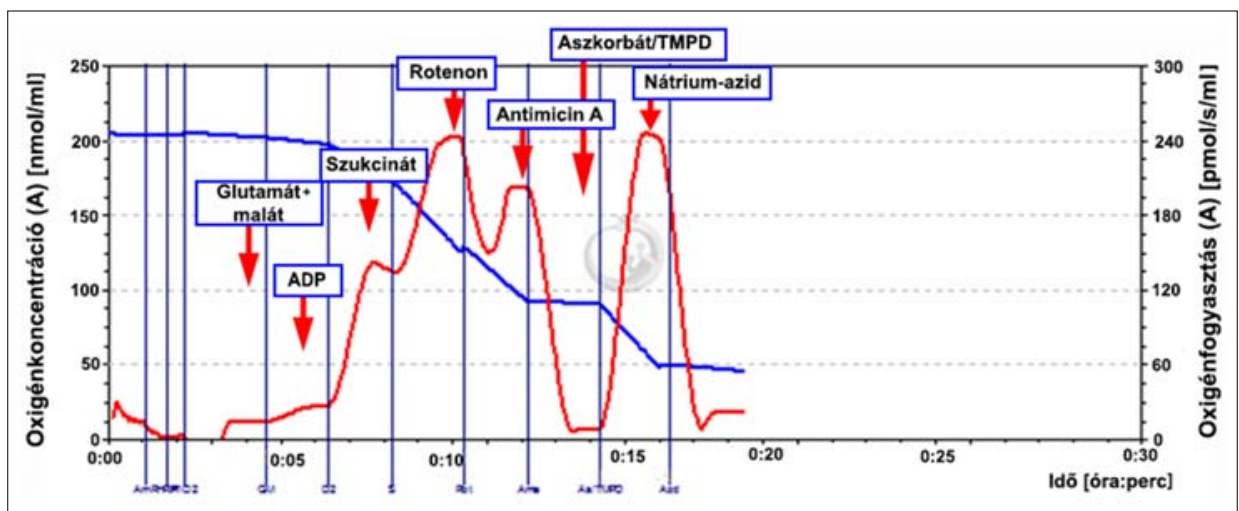

2. ábra. Egy nagy felbontású respirometriás mérés eredeti regisztrátuma 
tása. Antimicin $\mathrm{A}(2,5 \mu \mathrm{M})$ hatására a III. komplex gátlódik. Végül elektrondonorokkal (aszkorbát [2 mM]/ $N, N, N, N$-tetramethyl-p-phenylenediamin [TMPD] [20 $\mu \mathrm{M}]$ ) aktiváljuk a IV. komplexet, amit nátrium-aziddal ( $50 \mathrm{mM})$ lehet gátolni (2. ábra).

\section{Mütéti beavatkozás}

A sebészi beavatkozások során előforduló érkirekesztés következményeinek vizsgálatára részleges máj ischaemia/reperfúziós modellt alkalmaztunk altatott hím Sprague-Dawley patkányok (átlagos súly $300 \pm 20 \mathrm{~g}$, csoportonként hat-hat) felhasználásával, amelyeket ellenőrzött körülmények között, 12 órás nappal-éjszaka ciklusban, laboratóri- umi tápon tartottunk.

Az állatokat Na-pentobarbitállal altattuk (45 mg kg-1, intraperitonealisan), majd a jobb oldali vena jugularis externát és az arteria carotis communist kipreparáltuk. Az erekbe $22 \mathrm{G}$ méretü polietilén kanült vezettünk, a vénás kanülön keresztül történt szükség szerint a folyadékpótlás és az anesztézia fenntartása. A szabad légút biztosítására a tracheába tracheostomán keresztül 3 mm-es szilikonkanült helyeztünk.

Medián laparotomia után kétoldali subcostalis metszések történtek, a behatolási kapukból mobilizáltuk a májat, a vena portae hepatis ágait és az arteria hepaticát. Kontrollbiopszia után az arteria hepatica és a vena portae hepatis bal ágainak leszorításával a bal májlebeny teljes ischae-

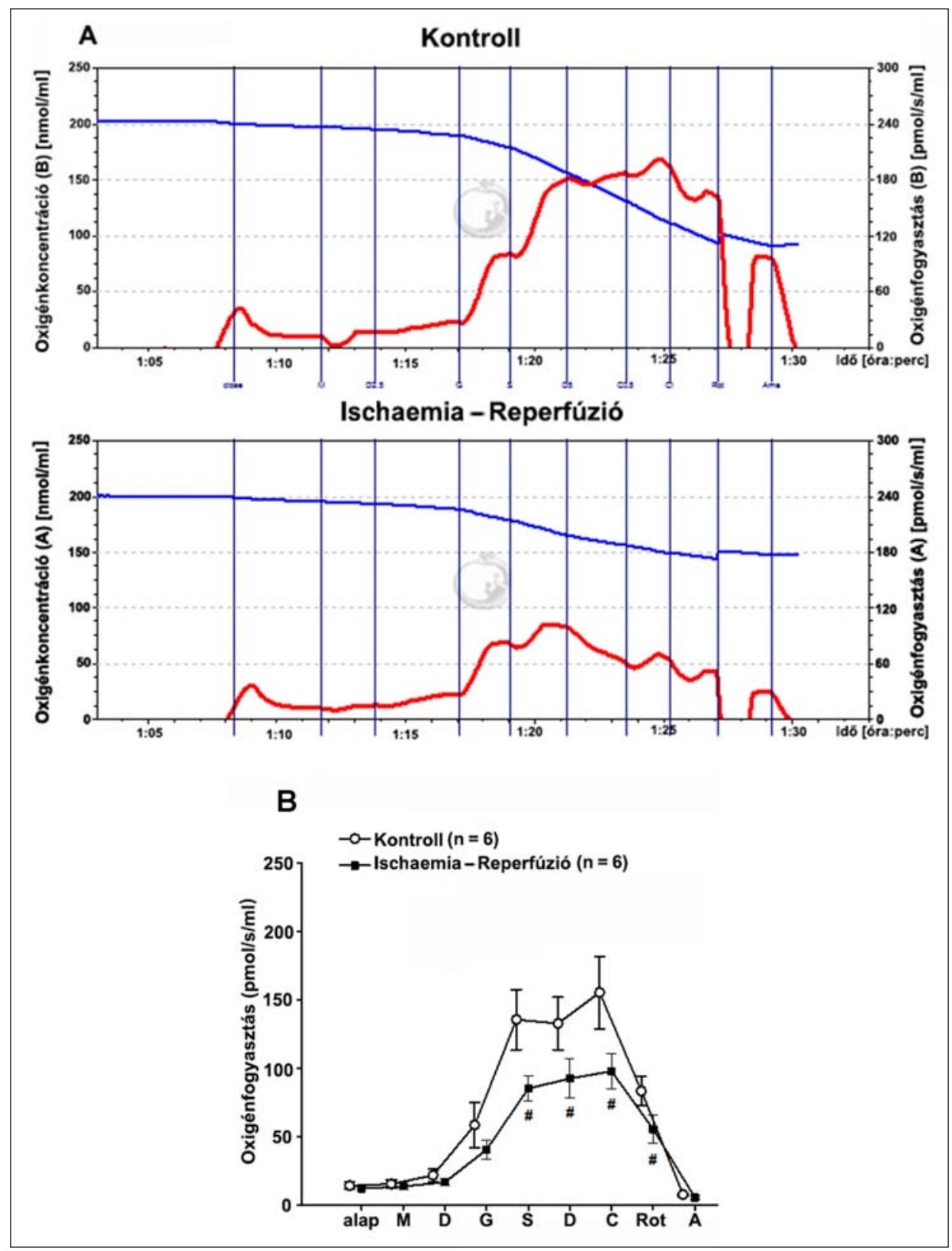

3. ábra. Ép és ischaemia/reperfúzión (IR) átesett májmitochondriumok oxigénfogyasztása. A) Eredeti regisztrátumok. B) Szubsztrát-szétkapcsolószer-gátlószer (SUIT) protokoll bemutatása. alap = alapvonal; $\mathrm{M}=$ malát; $\mathrm{D}=\mathrm{ADP} ; \mathrm{G}=$ glutamát; $\mathrm{S}=$ szukcinát; $\mathrm{C}=$ karbonil cianid 3-klorofenilhidrazon $(\mathrm{CCCP})$ szétkapcsolószer; Rot $=$ rotenon; $\mathrm{A}=\operatorname{antimicin} \mathrm{A}$ 
miáját hoztuk létre. Az egyórás időtartam után az ereket felengedtük, és a bal lebenyből a reperfúzió 60 . percében szövetmintákat vettünk, amelyeket üveghomogenizálóval jégen homogenizáltunk. Ezt követően a májmintákat a respirométer kamráiba helyeztük. Az oxigénfogyasztás intenzitásának mérése az egyes légzési komplexek számára hasznosítható szubsztrát-szétkapcsolószer-gátlószer protokollok szerint történt. A mérési eredményeket párhuzamosan álműtött, kontrollállatok májmintáinak értékeivel vetettük össze.

\section{Statisztikai analízis}

Az adatokat a SigmaPlot 12.5 statisztikai szoftver (Jandel Corporation, San Rafael, CA, Amerikai Egyesült Államok) segítségével értékeltük ki. A csoportok közötti különbségek kimutatásához kétutas ANOVA-t, majd ezt követően Bonferroni post hoc tesztet használtunk. Munkánk során az adatokat az átlag és átlag szórásaként (mean \pm SEM) tüntettük fel. A változásokat $p<0,05$ szint esetén tekintettük szignifikánsnak.

\section{Eredmények}

A 3. ábra eredeti regisztrátuma egy ischaemia/reperfúzió során károsodott és egy áloperált állatból származó májminta mitochondriumainak respirációs aktivitását ábrázolja. A különbség jól látható, az ischaemia/reperfúzió hatására jelentősen csökkent a légzési lánc kapacitása, vagyis az elektrontranszport hatékonysága, valamint szignifikánsan alacsonyabb oxidatív foszforilációs kapacitás $(120,7 \pm 6,2$ $\mathrm{pmol} / \mathrm{ml} / \mathrm{s}$ vs. $80,6 \pm 2,8 \mathrm{pmol} / \mathrm{ml} / \mathrm{s}$ ) észlelhetö. A mitochondriumok kapcsoltsága romlott $(140,9 \pm 3,09 \mathrm{pmol} /$ $\mathrm{ml} / \mathrm{s}$ vs. $90,2 \pm 3,09 \mathrm{pmol} / \mathrm{ml} / \mathrm{s})$, ami megnövekedett reaktívoxigén-szabadgyök termelödésére és a membrán károsodására utal. A légzési komplexek szelektív vizsgálatával az ischaemia/reperfúzió alatt kialakuló elektrontranszportlánc zavara mögötti oki tényezőként az I. komplex kiemelt szerepe igazolódott $(70,77 \pm 2,39 \mathrm{pmol} / \mathrm{ml} / \mathrm{s}$ vs. $40,9 \pm 2,05$ $\mathrm{pmol} / \mathrm{ml} / \mathrm{s}$ ).

\section{Megbeszélés}

A máj mitochondrialis funkciózavara kórjelző lehet számos esetben, például steatosis, cirrhosis, hepatocellularis carcinoma és cholangiocarcinoma esetén. ${ }^{6-8} \mathrm{~A}$ mitochondrialis légzési lánc zavarának kimutatására, vizsgálatára szolgáló módszer a közelmúltban kifejlesztett nagy felbontású respirometria, amelyet jelenleg még föleg kísérletes körülmények között használnak. Respirometriával kapott eredményeink megerősítik más kutatócsoportok eredményeit, miszerint a máj ischaemia/reperfúziós károsodása a mitochondrialis elektrontranszportlánc hatékonyságának és az I. komplex respirációs aktivitásának csökkenésével jellemezhetô..$^{8-11}$
A respirométer két csatornája párhuzamos méréseket tesz lehetővé, ami egyrészt a vizsgálat pontosságát növeli, valamint kísérletek során lehetővé teszi különböző kezelési csoportok azonnali összehasonlítását. Klinikai körülmények között kisméretü, homogenizált májmintákat lehet diagnosztikus célra használni, de a rendszer más mitochondriumpreparátumok mérésére is alkalmas: izolált mitochondriumok, szöveti homogenizátum, sejtszuszpenzió, izomrostok, illetve speciálisan metszett szövetdarabok is vizsgálhatók. ${ }^{12}$ A készülékkel, az oxigénfogyasztás mérésével párhuzamosan, ugyanazon mintából a teljes szabadgyök-produkció, mitochondrialis membránpotenciál, valamint a $\mathrm{Ca}^{2+}$-szint meghatározását is el lehet végezni.

A fentieket összefoglalva elmondhatjuk, hogy a respirometria alkalmasnak bizonyult az ischaemia/reperfúzióval járó mitochondrialis károsodás kimutatására és a légzési lánc aktivitásának mérésére. Saját kísérletes vizsgálataink és más kutatócsoportok eredményei is arra utalnak, hogy a respirometriás technika alkalmazásával lehetőség nyílhat a mitochondrialis diszfunkcióval járó humán májbetegségek klinikai diagnosztikájára, valamint egyes terápiás beavatkozások hatékonyságának növelésére is. ${ }^{11,13}$

\section{Kutatási támogatás: OTKA K104656}

\section{Irodalomjegyzék}

${ }^{1}$ Clavien PA, Oberkofler CE, Raptis DA, Lehmann K, Rickenbacher A, El-Badry AM: What is critical for liver surgery and partial liver transplantation: size or quality? Hepatology 2010; 52: 715-729

${ }^{2}$ Tevar AD, Clarke C, Wang J, Rudich SM, Woodle ES, Lentsch AB, Edwards ML: Clinical review of nonalcoholic steatohepatitis in liver surgery and transplantation. J Am Coll Surg 2010; 210: 515-526

${ }^{3}$ Vartak R, Porras CA, Bai Y: Respiratory supercomplexes: structure, function and assembly. Protein Cell 2013; 4: $582-590$

${ }^{4}$ Hall A, Larsen AK, Parhamifar L, Meyle KD, Wu LP, Moghimi SM: High resolution respirometry analysis of polyethylenimine-mediated mitochondrial energy crisis and cellular stress: Mitochondrial proton leak and inhibition of the electron transport system. Biochim Biophys Acta 2013; 1827: 1213-1225

${ }^{5}$ Pesta D, Gnaiger E: High-resolution respirometry: OXPHOS protocols for human cells and permeabilized fibers from small biopsies of human muscle. Methods Mol Biol 2012; 810: 25-58

${ }^{6}$ Jelenik T, Roden M: Mitochondrial plasticity in obesity and diabetes mellitus. Antioxid Redox Signal 2013; 19: 258-268

${ }^{7}$ Domenis R, Comelli M, Bisetto E, Mavelli I: Mitochondrial bioenergetic profile and responses to metabolic inhibition in human hepatocarcinoma cell lines with distinct differentiation characteristics. J Bioenerg Biomembr 2011; 43: 493-505 
${ }^{8}$ Gnaiger E, Kuznetsov AV, Schneeberger S, Seiler $R$, Brandacher $G$, Steurer W, Margreiter R: Mitochondria in the cold. In: Life in the cold. New York: Springer; 2000. p. 431-442

${ }^{9}$ Chu MJ, Hickey AJ, Jiang Y, Petzer A, Bartlett AS, Phillips $A R$ : Mitochondrial dysfunction in steatotic rat livers occurs because a defect in complex i makes the liver susceptible to prolonged cold ischemia. Liver Transpl 2015; 21: 396-407

${ }^{10}$ Chu MJ, Hickey AJ, Tagaloa S, Zhang L, Dare AJ, MacDonald JR, Yeong ML, Bartlett AS, Phillips AR: Ob/ob mouse livers show decreased oxidative phosphorylation efficiencies and anaerobic capacities after cold ischemia. PLoS One 2014; 9(6): e100609
${ }^{11}$ Strifler G, Tuboly E, Szél E, Kaszonyi E, Cao C, Kaszaki $J$, Mészáros A, Boros M, Hartmann P: Inhaled methane limits the mitochondrial electron transport chain dysfunction during experimental liver ischemia-reperfusion injury. PLoS One 2016; 11: e0146363

${ }^{12}$ Kuznetsov AV, Strobl D, Ruttmann E, Königsrainer A, Margreiter R, Gnaiger E: Evaluation of mitochondrial respiratory function in small biopsies of liver. Anal Biochem 2002; 2: 186-194

${ }^{13}$ De Andrade DC, de Carvalho SN, Pinheiro D, Thole AA, Moura AS, de Carvalho L, Cortez EA: Bone marrow mononuclear cell transplantation improves mitochondrial bioenergetics in the liver of cholestatic rats. Exp Cell Res 2015; 336: 15-22 